\title{
PENGEMBANGAN DESAIN MEDIA PEMBELAJARAN FISIKA SMA BERBASIS VIDEOPADA MATERI GELOMBANG BUNYI
}

\author{
Rexy Dwipangestu, Afrizal Mayub, Nyoman Rohadi \\ Program Studi Fisika JPMIPA FKIP Universitas Bengkulu \\ Jl Raya Kandang Limun No 1 Bengkulu 38123 \\ Email : Rexydp@gmail.com
}

\begin{abstract}
ABSTRAK
Penelitian ini merupakan penelitian research and development yang bertujuan untuk mengembangkan desain media pembelajaran fisika SMA berbasis video pada pokok bahasan gelombang bunyi yang valid dan reliabel. Tahap dalam penelitian ini meliputi potensi dan masalah, studi literatur dan pengumpulan informasi, desain produk, validasi desain, dan desain teruji. Media pembelajaran yang valid dan reliabel dihasilkan melalui validasi desain yang merupakan tahap pengujian produk secara internal melalui validasi isi oleh pendapat ahli dengan tiga aspek validasi yaitu, kualitas isi dan tujuan, kualitas instruksional, dan kualitas teknis dan kemudian diuji reliabilitasnya. Hasil penelitian menunjukkan bahwa, desain media pembelajaran yang dikembangkan dikategorikan sangat valid $(89,59 \%)$ dan rebilitas tinggi dengan koefisien 0,76 pada aspek kualitas isi dan tujaan, pada aspek kualitas instruksional dikategorikan sangat valid $(92,71 \%)$ dan reliabilitas sedang dengan koefisien 0,65 , dan pada aspek kualitas teknis dkategorikan sangat valid $(90,47 \%)$ dan reliabilitas sedang dengan koefisien 0,67 . Hasil total validasi dari tiga aspek sebesar $91 \%$ dengan kategori sangat valid.
\end{abstract}

\section{Kata kunci : Research and Development, Media Pembelajaran Video, Gelombang Bunyi}

\begin{abstract}
This study was a research and development research which aimed to develop the design of videobased high school physics learning media on the subject of sound waves are valid and reliable. Stages in the study include potentials and problems, literature studies and information gathering, product design, design validation, and tested design. A valid and reliable learning medium is generated through design validation which is the internal product testing stage through content validation by expert opinion with three aspects of validation, quality of content and objectives, instructional quality, and technical quality and then the media tested its reliability. The results showed that the design of learning media developed was categorized as highly valid (89.59\%) and high rebility with the coefficient of 0.76 on the content quality and idol aspects, the instructional quality was categorized as valid $(92.71 \%)$ and the reliability was with a coefficient of 0.65 , and on the aspect of technical quality categorized very valid $(90.47 \%)$ and moderate reliability with a coefficient of 0.67 . The total validation result of three aspects is $91 \%$ with very valid category.
\end{abstract}

Keywords : Research and Development, Video-based Learning Media, Sound Waves

\section{PENDAHULUAN}

Ilmu pengetahuan dan teknologi menjadi bagian yang tak terpisahkan dalam kehidupan sehari - hari manusia. Teknologi diciptakan dan dikembangkan sesuai dengan bidangnya dalam rangka membantu kegiatan hidup. Perkembangan teknologi yang semakin pesat tidak bisa dihindari dan berpengaruh terhadap dunia pendidikan. Dunia pendidikan senantiasa mengikuti perkembangan teknologi dalam rangka meningkatkan mutu pendidikan, terutama penyesuaian penggunaan teknologi informasi. Teknologi informasi memiliki pengaruh yang sangat besar terhadap manusia dalam melaksanakan proses pembelajaran dan memperoleh informasi. Teknologi informasi dapat dirancang dan dikembangkan menjadi sebuah media yang berfungsi sebagai alat bantu dalam proses pembelajaran.

Pembelajaran ilmu pengetahuan alam yang salah satunya fisika, yang sebagian besar materinya merupakan konsep-konsep yang abstrak dan sulit dipahami oleh siswa. Menurut 
Setyaningrum dan Wiyatmo, Fisika merupakan mata pelajaran yang membutuhkan pemahaman lebih, karena banyak ilustrasi gambar dan simbol, serta persamaan yang digunakan. Proses pembelajaran konvensional tentunya belum bisa menyajikan fenomena dan gejala alam yang bersifat abstrak[1]. Oleh kerena itu diperlukan media pembelajaran sebagai alat bantu penyaji meteri.

Menurut Hamalik media pembelajaran dapat membangkitkan motivasi dan minat siswa. Selain itu, penggunaan media dalam proses pembelajaran dapat membantu siswa untuk memperoleh pemahaman yang lebih baik, menyajikan data yang menarik dan terpercaya, memudahkan penafsiran data, dan memadatkan informasi. Siswa yang belajar dengan menggunakan media pembelajaran akan cenderung lebih tertarik untuk belajar dibandingkan siswa yang hanya belajar dengan cara mendengarkan penjelasan guru [2].

Guru yang inovatif dan kreatif harus mampu untuk mengembangkan dan menggunakan media pembelajaran yang sejalan dengan perkembangan ilmu pengetahuan dan teknologi. Terutama dalam hal mengembangkan media yang bisa digunakan untuk menjelaskan materi fisika yang sulit untuk ditampilkan di kelas. Misalnya, fenomena gelombang, gaya, cahaya, dan berbagai konsep abstrak lainnya. Sulit bagi guru untuk menjelaskan kepada siswa bagaimana bentuk gaya yang bekerja pada benda, ataupun sulit untuk menampilkan bagaimana gelombang bunyi merambat dari satu tempat ke tempat lainnya. Gelombang bunyi merupakan meteri fisika yang selalu ada dalam kehidupan sehari-hari, namun dalam proses pembelajaran sangat sulit untuk menjelaskan kensep - konsep gelombang bunyi tersebut . Kesulitan dalam menjelaskan konsep-konsep tersebut yang demikian itu membutuhkan suatu media pembelajaran.

Media pembelajaran yang digunakan dapat berupa multimedia. Menurut Rusman, dkk pembelajaran berbasis multimedia adalah kegiatan pembelajaran yang memanfaatkan komputer untuk membuat dan menggabungkan teks, grafik, audio, gembar bergerak (video dan animasi) yang memungkinkan pemakai untuk melakukan navigasi, berinteraksi, berkreasi, dan berkomunikasi [3]. Multimedia merupakan salah satu jenis media yang digunakan untuk kepentingan proses pembelajaran.

Heinich dkk menyatakan bahwa "klasifikasi media yang digunakan untuk aktivitas pembelajaran yang terdiri dari: 1) Media cetak; 2) Media pameran/dispay; 3) Media audio; 4) Media gambar bergerak/motion picture; 5) Multimedia". Multimedia merupakan produk dari kemajuan teknologi digital. Media ini mampu memberikan pengalaman belajar yang kaya bagi penggunanya[4]. Dengan multimedia interaktif hal yang abstrak bagi siswa dapat ditampilkan kehadapan mereka sehingga dapat menarik perhatian dan minat melalui pembelajaran berbasis multimedia, tanpa mengurangi fungsi media pembelajaran secara umum. Untuk menampilkan hal abstrak ini, digunakan salah satu unsur-unsur multimedia yaitu video.

Video merupakan media audiovisual yang mampu menyajikan informasi dalam bentuk teks, gambar bergerak, dan suara. Dengan keunggulan sebagai media audiovisual, video mampu memperlihatkan objek, tempat dan peristiwa. Konsep - konsep fisika yang abstrak dapat disajikan dalam bentuk video. Berdasarkan uraian di atas, dirumuskan masalah yaitu, pengembangan desain media pembelajaran fisika SMA berbasis video pada pokok bahasan gelombang bunyi yang valid dan reliabel? Tujuannya adalah untuk mengembangan desain media pembelajaran fisika SMA berbasis video pada pokok bahasan gelombang bunyi yang valid dan reliabel.

\section{METODE PENELITIAN}

Jenis penelitian yang digunakan dalam penelitian ini adalah penelitian dan pengembangan (research and development) dengan tipe rangcangan level 1. Dalam rancangan ini, peneliti melakukan penelitian tetapi tidak dilanjutkan dengan membuat produk dan tidak 
melakukan pengujian lapangan. Dengan demikian, penelitian yang dilakukan hanya menghasilkan rancangan produk dan rancangan tersebut divalidasi secara internal (pendapat ahli) tetapi tidak diproduksi atau diuji secara eksternal (pengujian lapangan) [5].

Penelitian ini dilakukan pada bulan Januari-Juli 2018 di SMA Negeri 6 Kota Bengkulu. Alat dan bahan untuk mengembangan desain media pembelajaran berbasis video dalam penelitian ini berupa satu unit laptop yang merupakan perangkat keras dan aplikasi pembuat dan pengubah video. Perangkat lunak yang digunakan berupa aplikasi, yaitu, macromedia flash 8, sparkol videoscribe, dan camtasia studio 8.

Instrumen yang digunakan berupa pedoman wawancara, lembar angket kebutuhan, dan lembar validasi. Pedoman wawancara dan angket kebutuhan digunakan untuk mengidentifikasi potensi dan masalah penelitian, sedangkan lembar validasi diberikan kepada ahli untuk mengetahui tingkat validitas desain media yang dikembangkan melalui uji validitas. Validasi desain media oleh ahli meliputi tiga aspek yaitu, aspek kualitas isi dan tujuan, aspekkualitas instruksional, dan aspek kualitas teknis.

\subsection{Uji Validitas}

Pengujian dilakukan berdasarkan pendapat ahli. Para ahli diberikan lembar validasi untuk menilai tingkat validitas media pembelajaran berbasis video pada pokok bahasan gelombang bunyi yang dikembangkan. Kriteria penilaian pada lembar validasi menggunakan skala Likert yang mempunyai gradasi dari sangat positif sampai sangat negatif, yang dapat berupa kata-kata antara lain:

Sangat Baik (SB) $\quad: 4$

Baik (B) : 3

Tidak Baik (TB) : 2

Sangat Tidak Baik (STB) : : $1[5]$

Sebelumnya dicari terlebih dahulu nilai rata-rata dari lembar validasi tersebut, rumus untuk mencari nilai rata-rata adalah sebagai berikut:

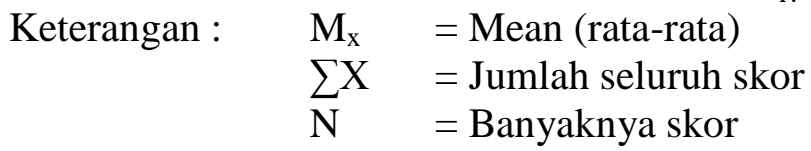

$$
M_{x}=\frac{\sum X}{N}
$$

Kemudian menentukan persentase nilai validasi menggunakan rumus:

$$
\operatorname{Validitas}(V)=\frac{\text { Total Skor validasi }}{\text { Total Skor Maksimal }} \times 100 \%
$$

Hasil validitas yang telah diketahui persentasenya dapat dicocokkan dengan kriteria validitas yang dapat dilihat pada tabel berikut:

Tabel 1. Kriteria Validitas [6]

\begin{tabular}{|c|c|c|}
\hline No & Persentase & Kriteria Validitas \\
\hline 1 & $85,1-100 \%$ & Sangat Valid \\
\hline 2 & $70,01-85,00 \%$ & Valid \\
\hline 3 & $50,01-70,00 \%$ & Tidak Valid \\
\hline 4 & $1,00-50,00 \%$ & Sangat Tidak Valid \\
\hline
\end{tabular}

\subsection{Uji Reliabilitas}

Setelah diuji validitas maka dilanjutkan dengan uji reliabiitas. Uji reliabilitas pada penelitian menggunakan perhitungan Alpha Cronbach karena instrumen penilaian yang digunakan berbentuk skala bertingkat. Rumus yang digunakan dinyatakan dengan sebagai berikut:

$$
\rho_{\alpha}=\frac{N}{N-1}\left(1-\frac{\sum \sigma_{i}^{2}}{\sigma_{A}^{2}}\right)
$$

Keterangan : 
$\rho_{\alpha} \quad=$ Koefisien reliabilitas

$N \quad=$ Jumlah Butir

$\sum \sigma_{i}^{2}=$ Jumlah varian butir atau Total Varian Butir

$\sigma_{A}^{2} \quad=$ Varian skor

Sebelum menghitung koefisien reliabilitas, varian skor dan total varian butir dihitung terlebih dahulu menggunakan rumus sebagai berikut:

$$
\begin{aligned}
& \text { Varian skor } \sigma_{A}^{2}=\frac{N \sum A^{2}-\left(\sum A\right)^{2}}{N^{2}} \\
& \text { Varian Butir } \sigma_{i}^{2}=\frac{N \sum B i^{2}-\left(\sum B i\right)^{2}}{N^{2}}
\end{aligned}
$$

Keterangan:

A = Jumlah Skor

$\mathrm{B}=$ Skor Butir

$\mathrm{N}=$ Banyaknya Validator atau banyaknya responden [7].

Kategori nilai koefisien reliabilitas mengacu pada pendapat Guilford :

Tabel 2 Kategori Nilai Koefisien Reliabilitas [8]

\begin{tabular}{|c|c|c|}
\hline No & Nilai Koefisien & Kategori \\
\hline 1 & $\leq 0,20$ & Sangat Rendah \\
\hline 2 & $>0,20-0,40$ & Rendah \\
\hline 3 & $>0,40-0,70$ & Cukup \\
\hline 4 & $>0,70-0,90$ & Tinggi \\
\hline 5 & $>0,90-1,00$ & Sangat Tinggi \\
\hline
\end{tabular}

\section{HASIL DAN PEMBAHASAN}

Penelitian ini menghasilkan desian media pembelajaran berbasis video pada pokok bahasan gelombang bunyi. Setelah melalui tahap pengembangan, dihasilkan desain media pembelajaran berbasis video sebagai berikut: a) Tampilan awal, menampilkan pokok bahasan utama yaitu gelombang bunyi, b) Pembagian bahasan materi, satu pokok bahasan dibagi menjadi empat bahasan, c) Kompetensi dasar dan indicator, d) Tujuan pembelajaran, ditampilkan sebelum memasuki penyajian materi, e) Penyajian materi, penyajian materi menggunakan pendekatan induktif, f) Animasi peristiwa konsep $\rightarrow$ Pengertian konsep $\rightarrow$ Formulasi, g) Kesimpulan, ditampilkan setelah penyajian materi pada tiap bahasan. Berikut merupakan beberapa gambar tampilan media pembelajaran berbasis video yang telah dikembangkan:

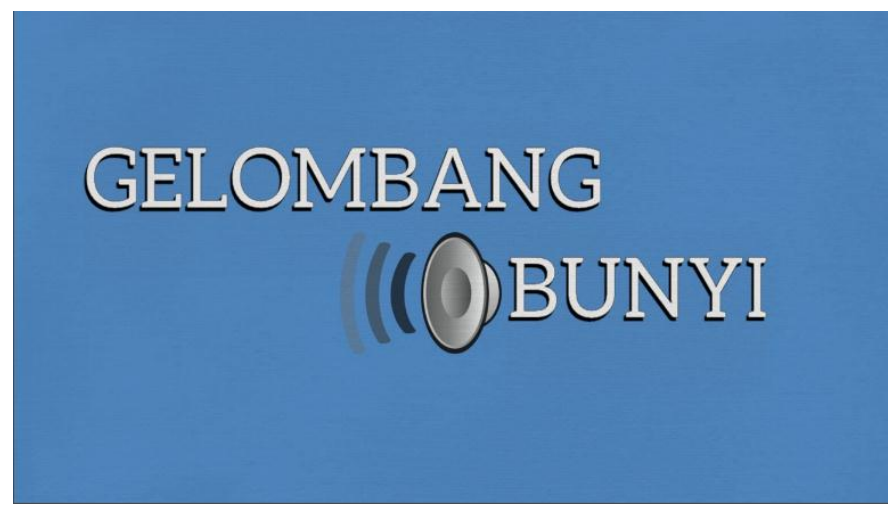

Gambar 1. Tampilan awal 

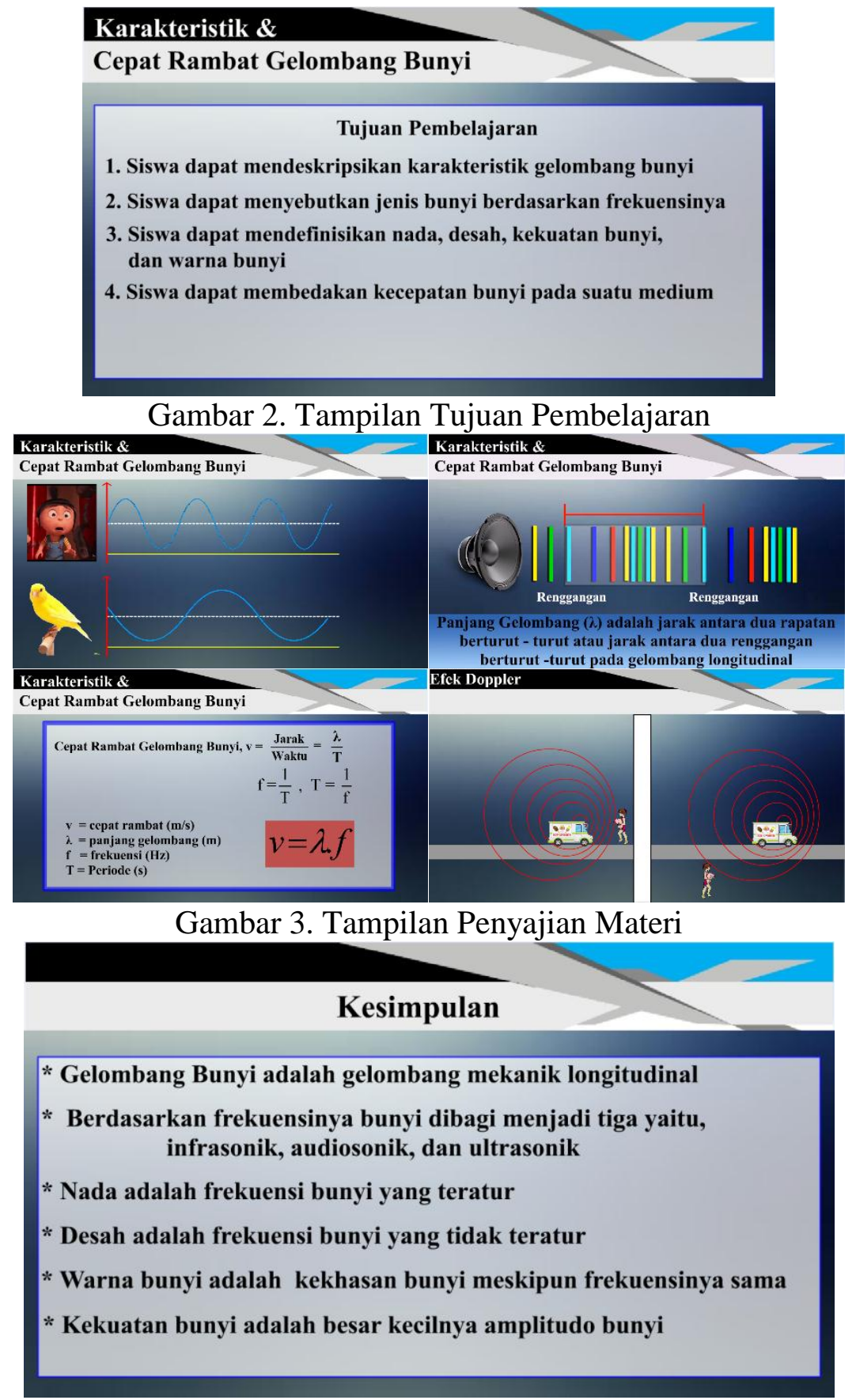

\subsection{Hasil Uji Validitas}

Gambar 4. Tampilan kesimpulan

Hasil validasi media pembelajaran berbasis video ini diperoleh dari uji validitas yang dilakukan oleh ahli. Hasil uji validitas pada aspek kualitas isi dan tujuan dapat dilihat pada tabel berikut:

Tabel 3. Hasil Uji validitas Aspek Kualitas Isi dan Tujuan

\begin{tabular}{|c|c|c|c|c|c|}
\hline Validator & $\sum$ Skor & $\begin{array}{c}\sum \text { Skor } \\
\text { Maks }\end{array}$ & $\begin{array}{c}\text { Rata }- \\
\text { rata }\end{array}$ & Persentase & Kategori \\
\hline Ahli 1 & 13 & 16 & 3,25 & $81,25 \%$ & Valid \\
\hline Ahli 2 & 14 & 16 & 3,5 & $87,50 \%$ & Sangat Valid \\
\hline Ahli 3 & 16 & 16 & 4 & $100 \%$ & Sangat Valid \\
\hline Total & 43 & 48 & 3,6 & $89,59 \%$ & Sangat Valid \\
\hline
\end{tabular}


Berdasarkan hasil uji validitas untuk aspek kualitas isi dan tujuan diketahui bahwa kualitas isi dan tujuan media pembelajaran yang dikembangkan sudah berada pada kategori sangat valid dengan persentase $89,59 \%$. Uji validitas untuk aspek kualitas instruksional terdiri dari delapan kriteria penilaian. Validasi pada aspek ini bertujuan untuk mengetahui kualitas pembelajaran yang dapat diberikan oleh media yang dikembangkan. Hasil uji validitas untuk kualitas instruksional dapat dilihat pada tabel berikut:

Tabel 4. Hasil Uji validitas Aspek Kualitas Instruksional

\begin{tabular}{|c|c|c|c|c|c|}
\hline Validator & $\sum$ Skor & $\begin{array}{c}\sum \text { Skor } \\
\text { Maks }\end{array}$ & $\begin{array}{c}\text { Rata }- \\
\text { rata }\end{array}$ & Persentase & Kategori \\
\hline Ahli 1 & 28 & 32 & 3,5 & $87,50 \%$ & Sangat Valid \\
\hline Ahli 2 & 30 & 32 & 3,75 & $93,75 \%$ & Sangat Valid \\
\hline Ahli 3 & 31 & 32 & 3,8 & $96,88 \%$ & Sangat Valid \\
\hline Total & 89 & 96 & 3,7 & $92,71 \%$ & Sangat Valid \\
\hline
\end{tabular}

Berdasarkan hasil uji validitas untuk aspek kualitas instruksional diketahui bahwa media pembelajaran yang dikembangkan sudah berada pada kategori sangat valid dengan persentase $92,71 \%$ yang mengacu pada kriteria validitas pada Tabel 3.2. Uji validitas untuk aspek kualitas teknis terdiri dari tujuh kriteria penilaian. Hasil uji validitas untuk kualitas instruksional dapat dilihat pada tabel berikut:

Tabel 5. Hasil Uji Validas Aspek Kualitas Teknis

\begin{tabular}{|c|c|c|c|c|c|}
\hline Validator & $\sum$ Skor & $\begin{array}{c}\sum \text { Skor } \\
\text { Maks }\end{array}$ & $\begin{array}{c}\text { Rata }- \\
\text { rata }\end{array}$ & Persentase & Kategori \\
\hline Ahli 1 & 24 & 28 & 3,4 & $85,71 \%$ & Sangat Valid \\
\hline Ahli 2 & 25 & 28 & 3,6 & $89,29 \%$ & Sangat Valid \\
\hline Ahli 3 & 27 & 28 & 3,8 & $96,43 \%$ & Sangat Valid \\
\hline Total & 76 & 84 & 3,6 & $90,47 \%$ & Sangat Valid \\
\hline
\end{tabular}

Berdasarkan hasil uji validitas untuk aspek kualitas teknis diketahui bahwa media pembelajaran yang dikembangkan sudah berada pada kategori sangat valid dengan persentase 90,47\%. Kategori ini mengacu pada kriteria validitas pada Tabel 3.2. Hasil total uji validitas dapat dilihat pada tabel berikut:

Tabel 6. Total Persentase Uji Validitas

\begin{tabular}{|c|c|c|c|}
\hline No & Aspek & Persentase & Kategori \\
\hline 1 & Kualitas isi dan tujuan & $89,59 \%$ & Sangat Valid \\
\hline 2 & Kualitas instrusional & $92,71 \%$ & Sangat Valid \\
\hline 3 & Kualitas Teknis & $90,47 \%$ & Sangat Valid \\
\hline \multicolumn{2}{r|}{ Rata - rata } & $91 \%$ & Sangat Valid \\
\hline
\end{tabular}

Secara keseluruhan, hasil uji validitas media pembelajaran fisika SMA berbasis video pada pokok bahasan gelombang bunyi mendapatkan persentase sebesar $91 \%$ yang dikategorikan sangat valid.

\subsection{Hasil Uji Reliabilitas}

Setelah diuji validitas maka selanjutnya uji reliabilitas. Uji reliabilitas dilakukan untuk mengetahui tingkat keajegan media yang dikembangkan. Untuk mengukur tingkat keajegan ini digunakan perhitungan reliabilitas Alpha Cronbach karena instrument yang diukur memiliki penilaian dengan skor berskala. Hasil uji reliabilitas dapat dilihat pada tabel berikut: 
Tabel 7. Hasil Uji Reliabilitas

\begin{tabular}{|c|c|c|c|}
\hline No & Aspek & Nilai Koefisien & Kategori \\
\hline 1 & Kualitas isi dan tujuan & 0,76 & Reliabilitas Tinggi \\
\hline 2 & Kualitas instruksional & 0,65 & Reliabilitas Sedang \\
\hline 3 & Kualitas teknis & 0,67 & Reliabilitas Sedang \\
\hline
\end{tabular}

Pembahasan hasil pengembangan desain media pembelajaran berbasis video berdasarkan tujan penelitian yaitu, untuk menghasilkan desain media pembelajaran berbasis video pada pokok bahasan gelombang bunyi yang valid dan reliabel. Karakteristik media berbasis video yang dikembangkan pada penelitian ini mampu memberikan penekananpenekanan pada bagian-bagian tertentu dalam pembelajaran dengan pendekatan saintifik (mengamati, menanya, mengumpulkan informasi, mengolah informasi, dan menarik kesimpulan).

1. Mengamati

Proses mengamati dapat dilakukan melalui kegiatan: melihat, menyimak, mendengar, dan membaca. Melalui animasi pada video kegiatan tersebut dapat dilaksanakan. Penyajian materi pada media video yang dikembangkan menuntun siswa untuk memperhatikan suatu konsep atau peristiwa fisika.

2. Menanya

Kegiatan "menanya" dalam kegiatan pembelajaran sebagaimana disampaikan dalam Permendikbud Nomor 81a Tahun 2013, adalah mengajukan pertanyaan tentang informasi yang tidak dipahami dari apa yang diamati atau pertanyaan untuk mendapatkan informasi tambahan tentang apa yang diamati. Materi pada video tidak dijelaskan secara langsung kepada siswa. Hal ini bertujuan untuk memberikan kesempatan bagi siswa untuk bertanya mengenai animasi konsep atau peristiwa fisika yang mereka lihat.

3. Mengumpulkan Informasi

Kegiatan "mengumpulkan informasi" merupakan tindak lanjut dari bertanya. Setelah muncul pertanyaan dari siswa, barulah animasi konsep atau peristiwa diberikan penjelasannya. Dalam Permendikbud Nomor 81a Tahun 2013, aktivitas mengumpulkan informasi dilakukan melalui eksperimen, membaca sumber lain selain buku teks, mengamati objek/ kejadian/, aktivitas wawancara dengan nara sumber dan sebagainya. Penggunaan media ini menuntun siswa untuk mengumpulkan informasi melalui pengamatan objek/ kejadian.

4. Mengolah Informasi

Kegiatan "mengasosiasi/ mengolah informasi/ menalar" dalam kegiatan pembelajaran sebagaimana disampaikan dalam Permendikbud Nomor 81a Tahun 2013, adalah memproses informasi yang sudah dikumpulkan baik terbatas dari hasil kegiatan mengumpulkan/eksperimen maupun hasil dari kegiatan mengamati dan kegiatan mengumpulkan informasi. Pada media yang dikembangkan, siswa mengolah informasi yang telah meraka kumpulkan dari pengamatan pada media.

5. Menarik Kesimpulan/ Mengkomunikasikan

Kegiatan "mengkomunikasikan" dalam kegiatan pembelajaran sebagaimana disampaikan dalam Permendikbud Nomor 81a Tahun 2013, adalah menyampaikan hasil pengamatan, kesimpulan berdasarkan hasil analisis secara lisan, tertulis, atau media lainnya.

Setelah desain media diuji validas dan reliabilitas. Desain tersebut diperbaiki berdasarkan saran dan masukan yang diberikan oleh ahli. Revisi dilakukan untuk menghasilkan produk akhir yang teruji. Pada penelitian ini telah dilakukan revisi untuk aspek kualitas isi dan tujuan. Revisi yang dilakukan adalah menambahkan contoh konsep penyampaian materi, memberikan detail pada formulasi yang ditampilkan, dan menambahkan penjelasan tanda positf atau negatif pada materi efek Doppler. 
Proses pengembangan produk dalam penelitian ini mengalami beberapa hambatan. Hambatan yang dihadapi saat mengembangkan media pembelajaran diantaranya, membuat animasi yang sesuai dengan konsep pada materi agar dapat memudahkan siswa untuk memahami materi, mencari efek suara yang sesuai animasi konsep, dan penambahan suara narasi mengalami hambatan karena terdapat gangguan suara dalam proses rekaman.

\section{KESIMPULAN DAN SARAN}

\subsection{Kesimpulan}

Berdasarkan penelitian yang telah dilakukan dan pembahasan yang telah dijabarkan dapat diperoleh media pembelajaran berbasis video pada pokok bahasan gelombang bunyi yang valid dan reliabel dengan rincian, aspek kualitas isi dan tujuan persentase $89,59 \%$ dinyatakan sangat valid dan reliabel tinggi dengan koefisien 0,76 , aspek kualitas instruksional persentase $92,71 \%$ dinyatakan sangat valid dan reliabel sedang dengan koefisien 0,65 , dan aspek kualitas teknis dengan persentase $90,47 \%$ dinyatakan sangat valid dan reliabel sedang dengan koefisien 0,67.

\subsection{Saran}

Saran pada penelitian ini yaitu, pada proses penambahan efek suara, jika memungkinkan efek suara lebih baik dibuat sendiri agar tidak menghabiskan waktu untuk mencari efek suara yang sesuai untuk penyajian materi. Kemudian penambahan suara narasi sebaiknya dilakukan ditempat sepi dan hening dalam proses rekaman agar tidak terdapat gangguan suara.

\section{UCAPAN TERIMA KASIH}

Terimak kasih kepada bapak Dr. Afrizal Mayub, M.Kom dan Drs. Nyoman Rohadi, M.Sc sebagai pembimbing sekaligus validator ahli dalam proses penelitian dan pengembangan desain media. Terima kasih kepada bapak Eko Risdianto, M.Cs, Ibu Desy Hanisa Putri, M.Si, dan Ibu Vera Anggreani, M.Pd.Si sebagai validator ahli yang menguji validitas desain media yang dikembangkan.

\section{DAFTAR PUSTAKA}

[1]Setyaningrum, A., \& Wiyatmo, Y. (2016). Pengembangan Video Pembelajaran Fisika Berbasis Sibi Pada Materi Getaran Dan Gelombang Sebagai Media Belajar Mandiri Untuk Meningkatkan Minat Belajar Pada Peserta Didik Tunarungu. Jurnal Pendidikan Fisika, Vol 5, No 1, 38-45.

[2]Arsyad, A. (2014). Media Pembelajaran. Jakarta: Rajawali Pers.

[3]Rusman, Kurniawan , D., \& Riyana, C. (2013). Pembelajaran Berbasis Teknologi Informasi dan Komunikasi. Jakarta: Rajawali Pers.

[4]Pribadi, B. A. (2017). Media dan Teknologi dalam Pembelajaran. Jakarta: PT Balebat Dedikasi Prima.

[5]Sugiyono. (2017). Metode Penelitian \& Pengembangan (Research and Development) untuk Bidang Pendidikan, Menjemen, Sosial, dan Teknik). Bandung: Alfabeta.

[6]Fatmawati, A. (2016). Pengembangan Perangkat Pembelajaran Konsep Pencemaran Lingkungan Menggunakan Model Pembelajaran Berdasarkan Masalah untuk SMA Kelas X. EduSains, Vol 4, No 2, 94-103.

[7]Susetyo, B. (2015). Penyusunan dan Analisis Tes untuk Penilaian Hasil Belajar Bidang Kognitif. Bandung: PT Refika Aditama.

[8]Jihad, A., \& Haris, A. (2012). Evaluasi Pembelajaran. Yogyakarta: Multi Pressindo. 